\title{
Discharge Capacity of Energy Storages as a Function of the Discharge Current -Expanding Peukert's equation
}

\author{
Christoph Nebl, Fabian Steger, Hans-Georg Schweiger* \\ Centre for Applied Research, Technische Hochschule Ingolstadt (THI), Esplanade 10, 85049 \\ Ingolstadt, Germany \\ *E-mail: hans-georg.schweiger@thi.de
}

doi: $10.20964 / 2017.06 .51$

Received: 27 July 2016 / Accepted: 16 March 2017 / Published: 12 May 2017

\begin{abstract}
In 1897 Wilhelm Peukert tested lead-acid batteries with constant current and observed that a single equation can describe the relationship between the discharge capacity of the battery and a constant discharge current. In this article the dependence of the discharge capacity of lithium-ion battery cells, electrochemical double-layer capacitors and lithium capacitors are investigated from low to very high discharge rates. From low to intermediate discharge rates, these energy storage devices show ideal Peukert behavior, but a deviation was observed at high discharge rates. The cells provide less charge than predicted by Peukert's Law. To describe this deviation, a new equation has been derived by expanding Peukert's law to very discharge rates. It is capable to describe the discharge behavior of lithium-ion battery cells, electrochemical double-layer capacitors and lithium capacitors from low to high discharge rates in an unequivocal way.
\end{abstract}

Keywords: discharge capacity, lithium-ion cell, electrochemical double-layer capacitors, lithium capacitors, capacity, Peukert equation, discharge current

\section{FULL TEXT}

(C) 2017 The Authors. Published by ESG (www.electrochemsci.org). This article is an open access article distributed under the terms and conditions of the Creative Commons Attribution license (http://creativecommons.org/licenses/by/4.0/). 